\title{
STATISTICAL ANALYSIS OF QUALITY PARAMETERS OF PIG IRON
}

doi: $\quad 10.2478 /$ czoto-2019-0078

Date of submission of the article to the Editor: 09/11/2018

Date of acceptance of the article by the Editor: 28/12/2018

Edyta Kardas ${ }^{1}$ - orcid id: 0000-0001-7699-2622

Pavlína Pustějovská ${ }^{2}$ - orcid id: 0000-0002-7073-3846

Silvie Brožova ${ }^{2}$ - orcid id: 0000-0002-1664-6442

${ }^{1}$ Czestochowa University of Technology, Poland, kardas.edyta@wip.pcz.pl

${ }^{2}$ VŠB-Technical University of Ostrava, Czech Republic

Abstract: Steel is currently main structural material in the world. Pig iron, which is the basic product of blast furnace process, is the semi-product used in steel-making processes. It is an alloy of iron with carbon containing above $2 \% \mathrm{C}$ and other elements with limited content, intended for further processing. Chemical composition of pig iron is its basic quality factor, it defines its class and meeting requirements set by steel plant department. It is important that this chemical composition is as stable as possible. In addition, the temperature of pig iron is also very important quality parameter. The paper presents statistical analysis of quality parameters of pig iron produced in one of Polish steelworks. The content of alloying elements and temperature of tapping of pig iron from blast furnace were examined. The amount of non-conforming production and the losses related to the low quality were assessed.

Keywords: pig iron, quality, quality parameters, statistical analysis

\section{INTRODUCTION}

Quality of products is one of main purpose of each production process. Quality is main factor that effects the customer satisfaction. The level of meeting of meeting their requirements must be checked all the time. The key element of quality guarantee is controlling quality parameters during and after production process in the company (Ingaldi and Kotus, 2018; Maszke et al., 2018; Ulewicz and Nový, 2018).

Methods of control of production processes have developed for over hundreds years. First methods were simple and primitive, mainly based on organoleptic checking of product and making simple measurements. Currently, various methods and techniques are used, they are supported by automatic devices and various mathematical and statistical technics are used to the analysis of results (Kozlowski and Liwowski, 2007). The production control can be divided into three main types:

- Technical inspection - checking the conformity of the product or assembled unit with technical conditions recognized and described in technical documentation related to the product (Zawora, 2008). 
- Quality control - is the extension of technical inspection. Its scope was increased to obtain a high degree of conformity of product with requirement of quality management system based on standard adopted by company. In addition, quality control includes: control of supplied material and parts, control of technological processes, control of finished products, supervision of measuring tools, improvement of control methods, the analysis of complaints and analysis of nonconformities in order to eliminate them (Zawora, 2008).

- Statistical quality control - is used to "random control" of production quality, carried out both during production process and after it is finished (Salacinski, 2016).

One of methods used to statistical quality control is PSC. Statistical Process Control is a method used in a production process using a statistical approach in the analysis of information obtained from the process. The main task of this method is the control of variability of process. I means that this method examines the discrepancy between the measurement results of the production process and whether they meet the requirements specified in specifications (Salacinski, 2016).

The most important task of the SPC is to keep the production process within the tolerance limit of so called centering the process in the absolute requirement during the course of each process. SPC as any process in companies must run in a rational way, not caused for the organization unnecessary increase in expenditure on the production process. SPC is also a kind of action scheme, that analyze two elements: value of dispersion and degree of process centering (Maszke et al., 2018; Ulewicz and Nový, 2018; Salacinski, 2016).

The article present the example of use of elements of SPC. The statistical analysis of parameters of finished product is made. As an example the quality parameters of pig iron were used.

\section{CHARACTERISTICS OF PRODUCT}

Steel is currently main structural material in the world. Production of crude steel in the world in 2017 was on the level of 1.689 billion $\mathrm{Mg}$, in 2016 - app. 1.627 billion $\mathrm{Mg}$ (production in 2017 increased by about $3.8 \%$ in relation to 2016), while in Poland in 2017 it reached the level of $10.3 \mathrm{mln} \mathrm{Mg}$, in 2016 - $9 \mathrm{mln} \mathrm{Mg}$ (increased by 14.5\%) (Steel Statistical Yearbook, 2018, www.worldsteel.org, 2018). Pig iron is semi-finished product used in steel production, so changes in the volume of pig iron production are largely connected to the level of steel production.

Pig iron is main product of blast furnace process. "It is an alloy of iron with carbon containing above $2 \% \mathrm{C}$ and other elements with limited content, intended for further processing in liquid state for steel or cast iron" (PN-93/H-01010/02, 1993). Due to high content of carbon and sulfur, it is a brittle alloy and is not suitable for forging, it is, therefore, not suitable for direct use (Czerminski, 1985). Table 1 presents limit value for the content of alloying elements in pig iron.

Chemical composition of pig iron is its basic quality factor, it defines its class and meeting requirements set by steel plant department. It is important that this chemical composition is as stable as possible. In addition, the temperature of pig iron is also very important quality parameter, that is taken into account by steelmakers. Many different factor influence on the temperature of pig iron: the volume of blast furnace (the larger volume of blast furnace, the higher temperature of pig iron), quality of ferrous burden materials, fuel quality, temperature of blast and its humidity (Sabela et al., 2005; Brozova et al., 2015). 
Table 1

Limit value of alloying elements in pig iron

\begin{tabular}{|c|c|}
\hline Element & Limit value \\
\hline Manganese & $\leq 30.0 \%$ \\
\hline Silicon & $\leq 8.0 \%$ \\
\hline Phosphorus & $\leq 3.0 \%$ \\
\hline Chrome & $\leq 10.0 \%$ \\
\hline Other alloying elements in total & $\leq 10.0 \%$ \\
\hline
\end{tabular}

Source: (PN - 93/H - 01010/02, 1993).

Si content in pig iron is the most critical elements for steelmakers. Minimizing the content of this element is economical, because (Benesh et al., 1997; Klimczyk et al., 2014):

- The fuel consumption in blast furnace is decreased,

- Causes shortening of steel melting time,

- Reduces the consumption of limestone and therefore the production of slag in steelworks.

Among steelworkers there is often the view that the content of $\mathrm{Mn}$ in pig iron should be within the range $0.8-0.9 \%$, because it has a positive effect on the course of bath desulfurization in steelmaking process (Parma, 1988). However, it requires the increase of coke consumption in blast furnace process. Therefore, lower manganese content in pig iron improves efficiency of production process.

In the analyzed Blast Furnace Department pig iron for steelmaking is produced. It is an alloy of iron with carbon containing more than $2 \%$ of this element. It is directly transported for further processing in convection-oxygen steel plant or pig casting machine (Technological instruction, 2018). In one blast furnace the production of pig iron is over $5000 \mathrm{Mg}$ per day. The basic criteria related to the content of alloying elements to be met by pig iron produced in the analyzed Blast Furnace Department are presented in Table 2 .

Table 2

Requirements for the content of individual alloying elements in pig iron

\begin{tabular}{|c|c|}
\hline Element & Content in pig iron \\
\hline $\mathrm{Si}$ & $0.50-0.80$ \\
\hline $\mathrm{Mn}$ & Above 0.20 \\
\hline $\mathrm{S}$ & Below 0.030 \\
\hline $\mathrm{P}$ & $\bullet \begin{array}{c}\text { Below } 0.11 \% \text { - rail steel } \\
\end{array}$ \\
\hline
\end{tabular}

Source: (Technological instruction, 2018).

\section{METHODOLOGY OF RESEARCH}

Quantitative analysis of pig iron produced in one of Polish steelworks was made. Statistical analysis of main quality parameters was conducted. The content of alloying elements ( $\mathrm{Si}, \mathrm{Mn}, \mathrm{P}, \mathrm{S}, \mathrm{C})$ and temperature of tapping of pig iron in the ladle were examined. Basic descriptive statistics were used: maximum value, minimum value, average, standard deviation and coefficient of deviation. Then, the changes in quality parameters during analyzed period of time were using cards of variation of parameters. Next, the quantitative analysis of non-conforming production of pig iron in 
the study period were made: for total non-conforming production and also divided in non-conforming content of $\mathrm{Si}$ and $\mathrm{S}$. In the last part of the paper, the analysis of amount of loss of pig iron in the study period was done.

The analysis cover two calendar years and includes parameter values and percentage of non-conforming production and amount of loss in pig iron in individual months. The results we gathered in Blast Furnace Department which is a part of one of the biggest Steel Plant in Poland.

\section{ANALYSIS AND DISCUSSION OF RESULTS}

The statistical analysis of content of basic elements in pig iron was made. Main descriptive statistics were calculated. Results of this analysis is presented in Table 3.

Table 3

Basic descriptive statistics for quality parameters of pig iron during the study period

\begin{tabular}{|l|r|r|r|r|r|}
\hline Parameter & \multicolumn{1}{|c|}{ Max. } & \multicolumn{1}{l|}{ Min. } & Average & Standard deviation & Coefficient of deviation \\
\hline Si content & 0.72 & 0.47 & 0.58 & 0.0615 & $10.1 \%$ \\
\hline Mn content & 0.31 & 0.12 & 0.19 & 0.0584 & $31.2 \%$ \\
\hline P content & 0.122 & 0.089 & 0.106 & 0.0099 & $9.3 \%$ \\
\hline S content & 0.036 & 0.022 & 0.027 & 0.0030 & $11.2 \%$ \\
\hline C content & 4.86 & 4.63 & 4.72 & 0.0550 & $1.6 \%$ \\
\hline Temperature & 1464.1 & 1442.5 & 1457.03 & 5.23 & $0.3 \%$ \\
\hline
\end{tabular}

Source: (Information materials, 2018).

The analysis of results presented in Table 3 shows that:

- Average Si content in pig iron was on the level of $0.58 \%$ with $10 \%$ deviation of this parameter. During the study period minimum value at level of $0.47 \%$ was noticed that means that requirements of minimum content of this element was exceeded.

- During the study period average content of $\mathrm{Mn}$ in pig iron was $0.19 \%$, while coefficient of deviation - over $30 \%$. It means that content of this element was under significant fluctuation and the average was a bit lower than requirements of minimum content of this element.

- P content in Pig iron fluctuated between 0.089 and $0.122 \%$. The average content was on the level $0.106 \%$, with deviation at the level of $9 \%$ of average value. The requirement for this element (for rail steel) was slightly exceeded.

- The average level of $S$ content in pig iron was $0.027 \%$ with deviation at the level of over $11 \%$ of average. This value was similar to the maximum requirement for the content of this element (0.03). Also maximum value for $S$ content $(0.036)$ also shows that requirement for this element content is exceeded very often.

- C content in pig iron was only under slight fluctuation, average content of this element was $4.72 \%$ with only $1.6 \%$ deviation.

- The temperature of pig iron was also relatively constant. The average temperature was at the level of $1454^{\circ} \mathrm{C}$ with only $0.3 \%$ deviation.

The analysis of changes of content of individual alloying elements and temperature of pig iron in particular month was made. Cards of variation of parameters of the average content of elements and temperature were used. Central line (CL) was set at the level of average value of the parameter, while lower line of control (LLC) and upper line of control (ULC) - as a sum and difference between the average and tripled standard deviation. The results of the analysis is presented in Figure 1. 
a)

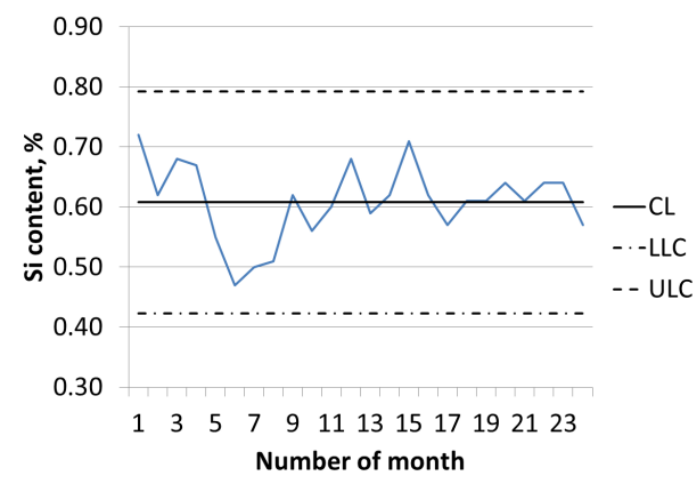

C)

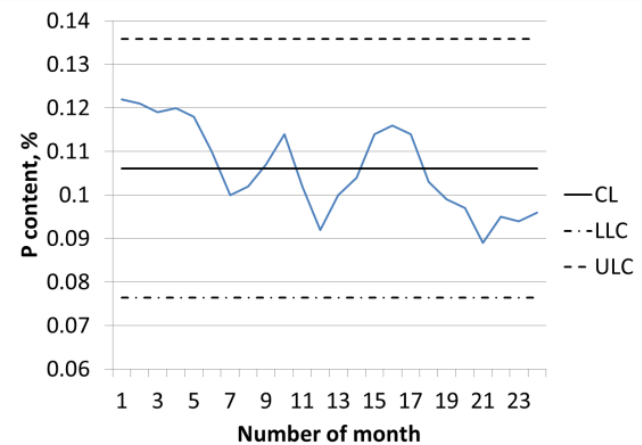

e)



b)

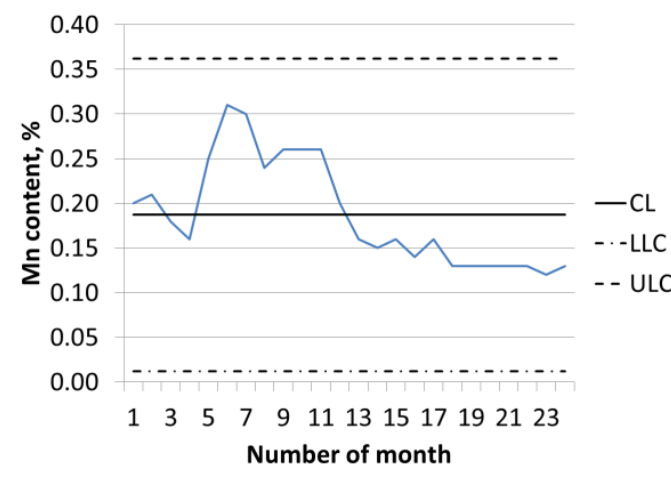

d)

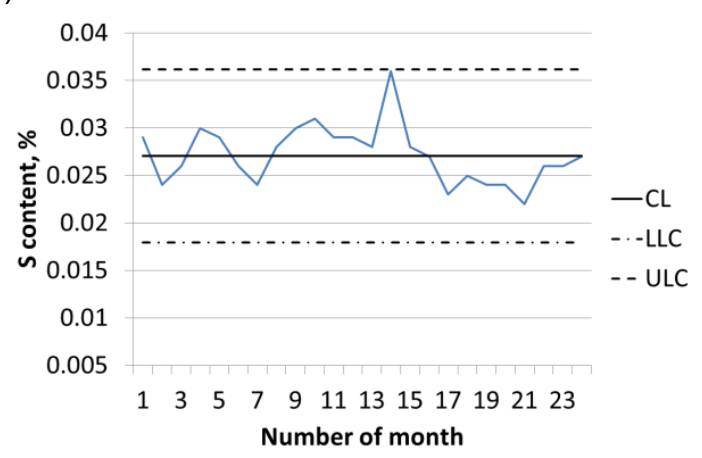

f)



Fig. 1. Analysis of content of chemical elements and temperature of pig iron in the study period: a) Si content, b) Mn content, c) $\mathrm{P}$ content, d) S content, e) C content, f) temperature Source: (Information materials, 2018).

The analysis of cards of variation of parameters of pig iron (Fig. 1) shows that:

- The value of average content of $\mathrm{Si}$ in pig iron $(0.61 \%)$ was in the middle of tolerance range for this parameter. In the first part of analyzed period of time lower value of this parameter was noticed (month 5-8). In month 6 the average monthly content of $\mathrm{Si}$ in pig iron was under minimum value $(0.47 \%)$, while in month 7 - was on the lower tolerance range limit. It must be underlined that the changes of content of this element went into slight fluctuation.

- Center line on the card of variation of Mn content in pig iron is on the level of $0.19 \%$ (average content of $\mathrm{Mn}$ ) and is a bit lower than lower tolerance limit for the content of this element. This parameter went into significant fluctuation. During first part of analyzed period of time the content of $\mathrm{Mn}$ was much higher than average value, while in the second part - much lower. 
- Lower and upper line of control for the card of variation of P content are much lower than upper tolerance limit for this element. Slight fluctuation of content of this element was noticed, but it should be said that on the in the second part of analyzed period of time lower value of this parameter were observed.

- Average content of S in pig iron was only a bit lower than upper tolerance limit for this element. Despite the small variation of content of $S$ in pig, iron, the maximum value of this parameter was exceeded. On the end of analyzed period of time the lower values of the parameter were observed.

- There are no limit for two parameters of quality of pig iron: C content and temperature. Cards of variation of these parameters show that value went into only very slight fluctuations ( $1.6 \%$ for $\mathrm{C}$ content and $0.3 \%$ for temperature).

The level of non-conforming production of pig iron was analyzed. Two critical parameters were taken into account: Si and S content in pig iron. Percentage of total non-conforming production in total but also divided in non-conforming content of $\mathrm{Si}$ and S. Results of the analysis are presented in Figure 2.

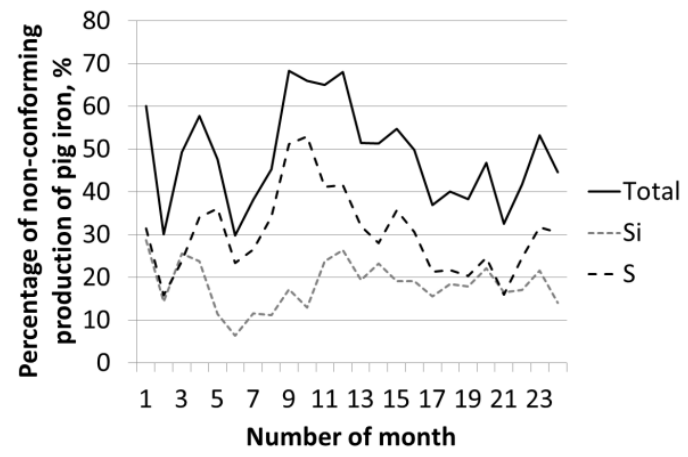

Fig. 2. Non-conforming production of pig iron in the study period Source: (Information materials, 2018).

After the analysis of the level of non-conforming production of pig iron in the study period it can be said that $47 \%$ of produced pig iron did not meet requirements for the parameters: $18 \%$ of total production was inappropriate content of $\mathrm{Si}$, while $29 \%$ of production - inappropriate content of $\mathrm{S}$. The level of total non-conforming production was in the range of 30 and $68 \%$. Larger percentage of non-conforming production did not meet requirement of $S$ content. Average non-conforming production with inappropriate S content was on the level of $29 \%$, the lowest percentage was $16 \%$, while the highest $-53 \%$. In case of $\mathrm{Si}$ content the average non-conforming production was on the level of $18 \%$ in the range of 6 to $29 \%$. Observing the changes of the parameters it can be said that the level of non-conforming production with inappropriate Si level went into smaller fluctuation than $\mathrm{S}$.

It should be noted that most of non-conforming production of pig iron is sent for further processing to steel plant department. However, the use of such pig iron requires changes in the amount of additives used during the steelmaking process, what have a significant impact on the manufacturing costs.

Some blast furnace production is treated as a loss. The level of loss of pig iron during production process was determined. Results of the analysis is presented in Figure 3.

As it can be seen in Figure 3 the average loss of pig iron in the study period is app. 18 thousands $\mathrm{Mg}$ per month. In month 9 the value of 30 thousands $\mathrm{Mg}$ was exceeded, in 
19 - was almost equal. In many cases high value of loss in production was caused by problems with quality of charge materials and fuels but also by break-down of equipment. The amount of production that was treated as a loss is classified as scrap which can be forwarded to reprocessing.

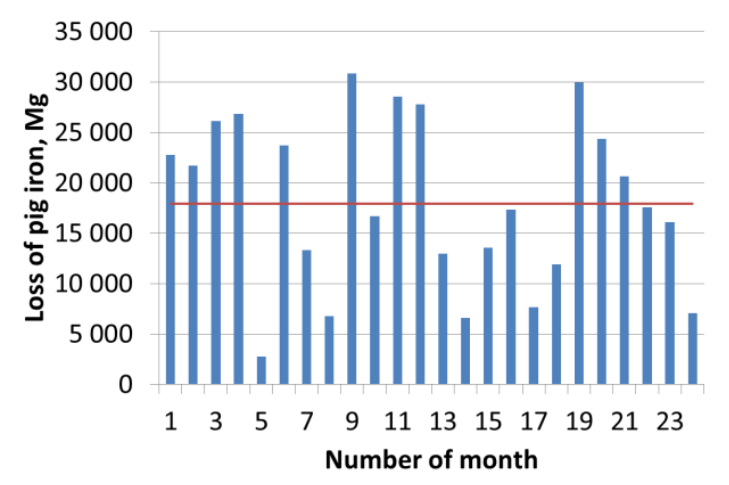

Fig. 3. The amount of loss of pig iron in the study period

Source: (Information materials, 2018).

\section{CONCLUSION}

The main purpose of blast furnace process is to produce pig iron with a stable chemical composition in accordance with steelworks requirements. Supplied pig iron that does not meet requirements results in a significant increase in steel production costs. It should be remembered that production of pig iron is carried out in such way as to minimize the costs of its production, what often is reflected in its poor quality. However, steel plant requirements often significantly increase cost of pig iron production (e.g. increasing costs of fuels).

Using elements of the SPC method can be used to assess the basic parameters of the pig iron and indicate the factors that affect their values. The analysis presented in the paper showed that maintaining the stable chemical composition of pig iron is not easy. The results of the analysis of parameters indicate their deviation and frequent exceeding of the limit values. This is a problem for the steelworkers, because it significantly increases the cost of steel production. The changes in content of chemical elements in pig iron are influenced by many factors, among which some of the should be mentioned:

- Ferrous materials quality: optimal preparation of basic ferrous material for production of pig iron (sinter) has a significant impact on the blast furnace process and quality of pig iron. The use of poor-quality ferrous materials increases the amount of by-products (e.g. slag), worsens the quality of pig iron, increases consumption of fuels, the value of which is the main part of production costs.

- Quality and type of fuels: the use of high-quality fuels, such as blast furnace coke) allows for optimal running the process, maintaining the parameters of its operation at optimal level. The use of cheaper sort of fuels at appropriate quantities can worsen the operation of the device and extend the time of melting and affect the chemical composition of the finished product.

- Operation parameters of the device: appropriate distribution of materials inside the blast furnace and the maintenance of parameters at constant, optimal level result in the equal operation of device. Disruption of these parameters can have significant impact on the duration of melting process, processes occur in the blast 
furnace, what can also cause disturbances in the quality of pig iron. It can also significantly reduce the campaign time of the device and cause break-downs.

In order to improve the quality of pig iron ad maintain quality parameters at a stable level, the attention should therefore be paid to the following factors: quality of materials and fuels, including the maintenance of quality parameters at a relatively constant level; optimal process parameters; uniform distribution of materials inside the blast furnace; intensification of blast furnace process; maintenance of blast furnace machinery and equipment, because this device is not new; improvement of processes of acceptance of pig iron and optimization of cost not at the level of each departments separately, but for both together.

\section{REFERENCES}

Benesh, R., Łędzki, A., Kopeć, R., Stachura, R. 1997. Study of the $\mathrm{SiO}_{2}$ reduction in blast furnace slag in the aspect of minimizing Si content in pig iron. VII International Scientific Conference Iron \& Steelmakig, Mala Lucivna, 60-63.

Brozova, S., Pustejovska, P., Jursova, S., Ingaldi, M., Vontorova, J., 2015. Economic Assessment Of Secondary Materials Generated In Metallurgical Companies. 24th International Conference On Metallurgy And Materials, Brno, 1866-1870.

Czerminski, J. 1985. Encyclopaedia of technology. Metallurgy. Publishing House Slask, Katowice.

Information materials, 2018. Blast Furnace Department of Steelworks X.

Ingaldi, M., Kotus, M., 2018. Assessment of Customer Satisfaction as an Element Deciding About Enterprise's Competitiveness. MAPE 2018, 1(1), 657-664. DOI: 10.2478/mape-2018-0083

Klimczyk, A., Bernasowski, M., Stachura, R., Ledzki, A., 2014. Reduction Of Silicon In Blast Furnace. METAL 2014: 23rd International Conference On Metallurgy And Materials, Brno, 159-164.

Kozlowski, R., Liwowski, B., 2007. Basic Issues of Production Management. Wolters Kluwer Polska, Warsaw.

Maszke, A., Dwornicka, R, Ulewicz, R., 2018. Problems in the Implementation of the Lean Concept at a Steel Works - Case Study. MATEC Web of Conferences, 183, DOI: $10.1051 /$ matecconf/201818301014

Parma, V. 1988. Correlation between the content of manganese and silicon and sulphur in pig iron. Metallurgy - Metal Engineering, 55(4), 111-114.

PN - 93/H - 01010/02, 1993. Metals. Definition and classification of pig iron. Polish Committee of Standardization.

Sabela, W., Brzezinski, P., Buzek, J., 2005. Factors affecting the costs of obtaining metallic iron, Metallurgy - Metal Engineering. 72(10), 490-496.

Salacinski, T., 2016. PSC - Statistical Control of Production Processes, Publishing House of Warsaw University of Technology, Warsaw.

Steel Statistical Yearbook, 2018. World Steel Association, Belgium.

Technological instruction, 2018. Instruction of blast furnace process. Internal print.

Ulewicz, R., Nový, F., 2018. Quality Management in the Process of Selection of Material for Dump Truck Elements. MAPE 2018, 1(1), 665-671. DOI: 10.2478/mape-2018-0084,

www.worldsteel.org 2018.

Zawora, J., 2008. The Basics of Machine Technology, School and Pedagogic Publishing Office, Warsaw. 